\title{
DLC Kesici Takım ve İșleme Parametrelerinin Yüzey Kalitesine ve Kesme Kuvvetlerine Etkilerinin İncelenmesi
}

\author{
Ayhan Etyemez ${ }^{1 *}$ \\ ${ }^{1}$ Nikken Türkiye Küçükyalı İş Merkezi A Blok No:5 Maltepe 34852 İstanbul, Türkiye (ORCID ID: 0000-0001-8188-2743)
}

(First received 1 June 2019 and in final form 1 July 2019)

(DOI: $10.31590 /$ ejosat.573269)

ATIF/REFERENCE: Etyemez, A. (2019). Investigation of the Effects of DLC Cutting Tool and Machining Parameters on Surface Quality and Cutting Force. European Journal of Science and Technology, (16), 494-504.

\section{$\ddot{O ̈ z}$}

Bu çalışmada, Al 7075 alaşımın Diamond Like Carbon (DLC) kaplamalı kesici takımlarla frezelemede yüzey pürüzlülüğü ve kesme kuvvetleri deneysel olarak incelenmiştir. İlerleme, devir ve talaş derinliğinin yüzey pürüzlülügüne ve kesme kuvvetlerine etkisi araştırılmıştır. Deney tasarımında Taguchi metodu kullanılmıştır. Bu yöntem ile deneylere sarfadilecek zaman ve maliyetten tasarruf edilmiş, deney neticelerinde elde edilen veriler optimize edilerek iyileştirme gerçekleştirilmiştir. Bağımlı ve bağımsız değişkenler arasındaki ilişki matematiksel olarak regresyon analiz yöntemiyle modellenmiştir. Sonuç olarak da ANOVA ile de yüzeydeki pürüzlülüğün oluşumunda en etkili faktör \%92,46 ile ilerleme, kesme kuvveti oluşumunda en etkili faktör \%82,91 ile talaş derinliği olduğu anlaşılmıştır. Regresyon analizi ile de Ra tahminsel denklemi \%94,7 doğruluk ile, kuvvet tahminsel denklemi \%87,1 doğruluk ile elde edilmiştir. Taguchi metodunun uygulandığı bu çalışmada kesme kuvveti ve yüzey pürüzlülüğü gibi işleme yöntemlerinde en aza indirilip, performans yükseltilmiş ve elde edilen ürün kalitesi iyileştirilmiştir.

Anahtar Kelimeler: DLC kaplı takımlar, Alüminyum 7075, Taguchi, Regrasyon Analizi, Varyans Analizi (ANOVA), Yüzey Pürüzlülüğü

\section{Investigation of the Effects of DLC Cutting Tool and Machining Parameters on Surface Quality and Cutting Force}

\begin{abstract}
In this study, the surface roughness and cutting forces of Al 7075 alloy were investigated experimentally while milling with cutting tool coated by Diamond-Like-Carbon (DLC). The influence of feed, cutting speed and depth of cut on surface roughness and cutting forces was analyzed. Taguchi technique was used when designing the experiment. With this way, the time and cost of the experiments economized, and the data found from the experimental outcomes were adjusted, and improvement was performed. The connection between the dependent and independent variables was modeled mathematically by regression analysis method. As a result, the most effective factor in the formation of surface roughness with ANOVA was the feed with $92.46 \%$, the most effective factor in the creation of cutting force was the depth of cut with $82.91 \%$. With the regression analysis, Ra's predictive equation was obtained with an accuracy of $94.7 \%$, and the force estimation of the equation with $87.1 \%$ accuracy. In this study where the Taguchi method has been applied, the processing methods such as cutting force and surface roughness have been minimized, the performance has been increased, and the product quality has been improved.
\end{abstract}

Keywords: DLC coated tools, Aluminium 7075, Taguchi, Regression Analysis, Variance Analysis (ANOVA), Surface Roughness

\footnotetext{
* Corresponding Author: Ayhan Etyemez, ${ }^{1}$ Nikken Türkiye Küçükyalı İş Merkezi A Blok No:5 Maltepe 34852 İstanbul, Türkiye, (ORCID ID: 00000001-8188-2743), ayhan@ nikken.com.tr
} 
European Journal of Science and Technology

\section{Introduction}

Al 7075 alloy is a lightweight material with high strength. However, in the experimental study; the fact that the workpiece is an aluminum alloy brings some problems. Al and its alloys are the materials that cause problems such as the wrapping and adhesion of the cutting tool and workpiece, especially in dry milling due to their material structure. The wrapping event has a negative effect on both the cutting tool and workpiece surface quality and adversely affects the machining performance in general. To eliminate this negativity, it is necessary to use either diamond and similar cutting tools or coolant to eliminate the winding and adhesion properties of the aluminum alloy. Since milling has a batch and pulse processing technique, the use of tools such as diamonds and the like will cause mechanical wear to the tool. Although the use of refrigerant during cutting is preferable because it contributes to the breakability of the chip and the removal of the broken chips from the cutting zone, it is an undesirable method to be preferred today when environmental conditions are taken into consideration.

Considering the above conditions, the lifetime of the cutting tool is increased, and the workpiece is produced in the desired quality, and it is necessary to optimize the cutting performance and situations in order to minimize the raw material consumption. In order to accomplish this, the issues affecting the lifetime of the cutting tools and the factors that influence the quality of the workpiece are being investigated by scientists. Studies conducted for many years show that there are many parameters and situations in milling that affect cutting tool life and workpiece quality. Cutting tool life and factors affecting the quality of the product produced are parameters such as the material of the cutting tool, geometric properties, coating, progression, cutting speed, depth of cut, coolant, chip breaker form, workpiece and the stiffness ratio of the cutting tool [1-3]. The selection of these parameters in accordance with the material of the workpiece; increasing the tool life and the surface quality of the product produced reduces the production cost and the energy consumed [4-9]. Taking all these into consideration, it is important to consider the selection of cutting parameters that are suitable for the workpiece material feature. Especially in the milling and machining of aluminum material and adhesion and diffusion of the cutting tool with the workpiece and the fact that the mechanical properties are not good due to intermittent processing are the features that should be considered.

In addition, reducing environmental damage is one of the other issues that should be considered as much as possible during the production period. Today, when the products compatible with the environment and environmental health are popular, it is necessary to create environmentally compatible environments as much as possible in the production process of these products and to manufacture them in these environments. In this case, dry machining comes into the foreground in machining [10]. Thus, the damage to the environment by the refrigerant liquids will be eliminated. It is difficult to manufacture without the use of refrigerants. Thanks to refrigerants, the temperature created due to friction are reduced between the cutting tool and the workpiece; it helps the chips to break away from the cutting zone and break it [6]. Failure to use coolers will cause the problems mentioned above to occur. Coating technology is utilized to minimize these problems. Considering the characteristics of the workpiece, in the manufacture of the coated cutting tools, heat formation and the pile of wood were tried to be drawn down [11]. Diamond materials are very high anti-adhesive properties due to their internal structure [11-13]. However, diamond cutting tools are damaged due to the impacts in batch operation, and tool life is negatively affected. Therefore, it is suggested that diamond-like carbon DLC coatings are more suitable than using cutting tools with many uncrystallized films in batch operations. DLC films resemble diamond in many aspects such as hardness, excellent wear and slipperiness, chemical stability, high electrical resistance, and high optical visibility. Due to their high hardness and low friction rate, diamond-like carbon DLC coatings have a high potential for dry and batch machining [4-5, 12-15]. In this study, the chip was removed from Al 7075 alloy material by using diamond-like carbon DLC coated cutting tools suggested by numerous researchers in the machining of aluminum alloys. Test conditions were determined by taking the current literature researches and the machining conditions of the companies in the industry into consideration. Cutting force was observed in the study of the experiment. The surface quality of the end product was examined, and a connection between the alteration in cutting parameters and surface quality was proved to be found.

The test results (surface roughness and cutting force) were optimized by using the Taguchi method, which is one of the optimization techniques usually used in literature, and the parameters were optimised. The analysis of variance (ANOVA) was used to determine the valid parameters and effect rates. In the results obtained from the experimental study with ANOVA; the most effective factor in the formation of surface roughness is feed with $92.46 \%$, the most effective factor in the formation of cutting force is the depth of cut with $82.91 \%$. The regression model was used to analyze the equation between dependent variables and independent variables. With the regression analysis, Ra's predictive equation was obtained with an accuracy of $94.7 \%$, and the force estimation of the equation with $87.1 \%$ accuracy.

\section{Experimental Study}

\subsection{The Method of Experiment}

The examples used in the test study were Al 7075 alloy material, and Al 7075 aluminum alloy, chemical ratios of which are given in Table 1 and mechanical specification of which are given in Table 2 was used as the test sample. In the tests, $x-y-x$ axial VMC$850 / 550+$ APC CNC Fanuc 0T of JOHN FORD CNC Milling Machine with 30 HP engine power was used. 
Table 1. Chemical properties of Al 7075

\begin{tabular}{ccccccc}
\hline $\mathrm{Al}$ & $\mathrm{Cu}$ & $\mathrm{Mn}$ & $\mathrm{Si}$ & $\mathrm{Ti}$ & $\mathrm{Zn}$ & $\mathrm{Cr}$ \\
\hline Remaining & 2,0 & 0.30 & 0.13 & 0.20 & 0.5 & 0.28 \\
\hline
\end{tabular}

Table 2. Mechanical properties of Al 7075

\begin{tabular}{lcccc}
\hline Tensile Strength (Mpa) & Yield Strength (Mpa) & $\begin{array}{l}\text { Elongation } \\
(\%)\end{array}$ & Density $\left(\mathrm{kg} / \mathrm{m}^{3}\right)$ & Hardness (HB) \\
\hline 570 & 505 & 11 & 2800 & 160 \\
\hline
\end{tabular}

In this experimental study, DL1000 AXET 123504PEFR-S hard metal inserts were used. Surface roughness was measured with MAHRPerthometer. The KISTLER 9265B force sensor, the KISTLER 5019B load amplifier and the DynaWare program as an analysis program were used to measure the force (Figures 1 and 2).

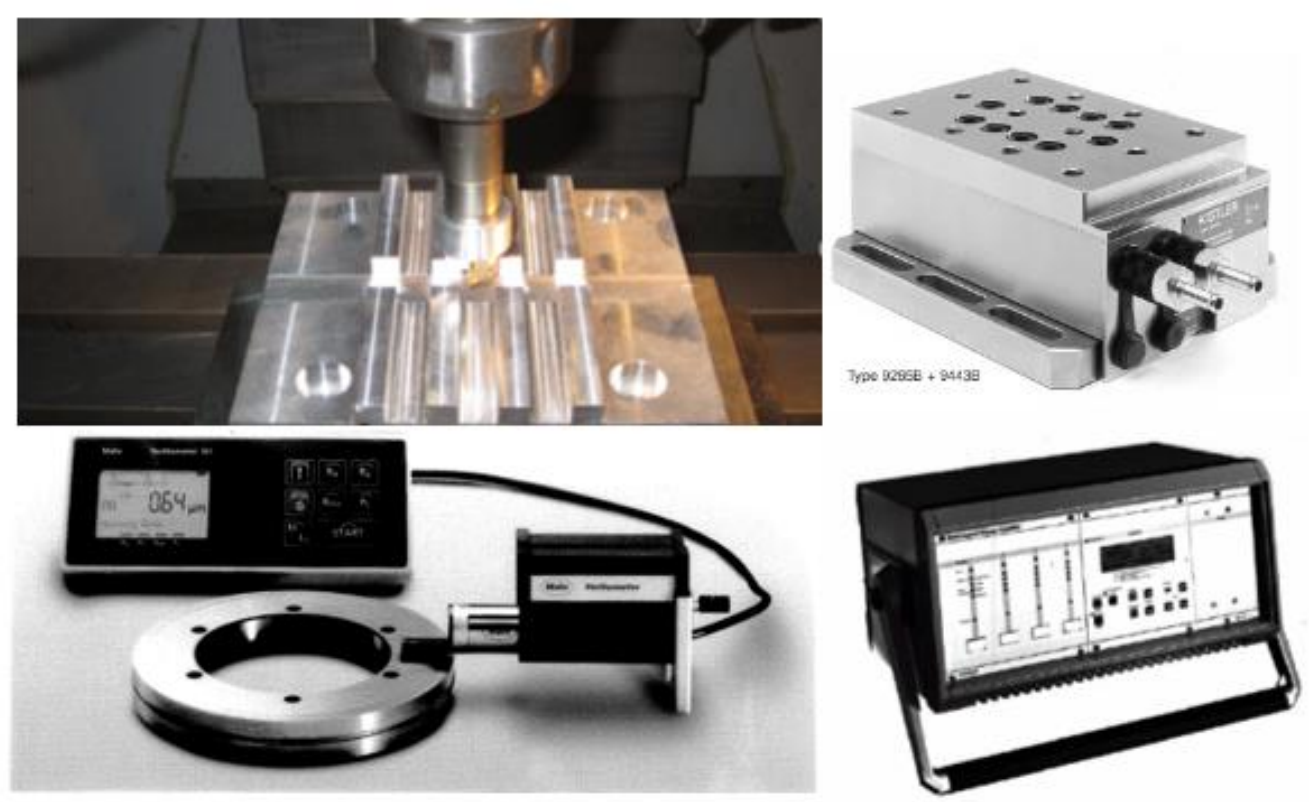

Figure 1. Test Arrangement
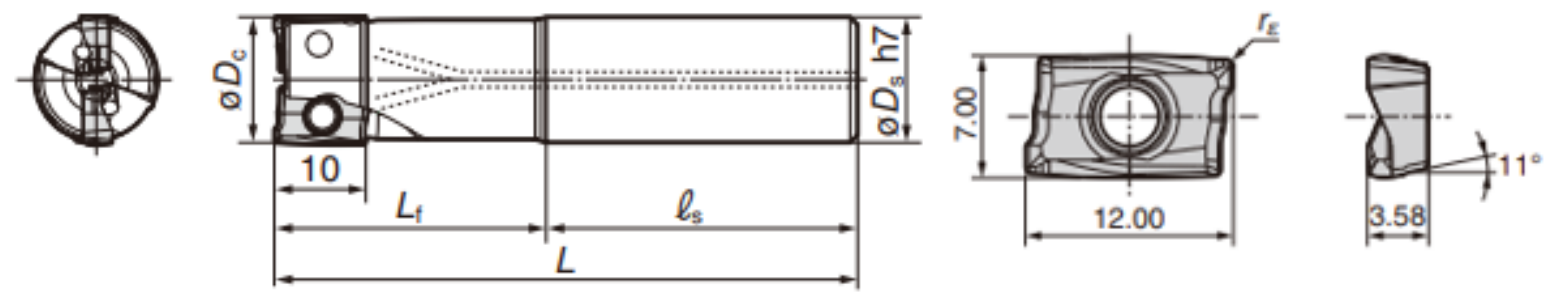

Figure 2. Holder and tool used in the experiment

\subsection{Test Design}

The experiment design was done by using Taguchi technique. As a result, it was probably to reach more wide-ranging outcomes with less experimentation. Thus, time and cost savings were provided [16-23]. When determining the quality characteristics, for the surface roughness and cutting force ratios to be measured are desired to be the least, the principle of "the smallest is the best" was applied.

$S / N(\eta)=-10 x \log \left(\frac{1}{n} \sum_{i=1}^{n} y_{i^{2}}\right)$

$\mathrm{N}=$ the number of experiments performed in experimental conditions and y expresses the measured characteristic (dependent variable). 
The study of the experiment, feed (f), rotation $(\mathrm{N})$, and depth of cut $(\mathrm{d})$ were selected as parameters. DLC coated DL1000 AXET 123504PEFR-S insert ends were used in all experiments. The parameters and their levels to be used in the test are presented in Table 3, and the test design of L9 is presented in Table 4.

Table 3. Test parameters

\begin{tabular}{cccc}
\hline Parameters & $\begin{array}{c}(\mathrm{A}) \\
\text { Progress } \\
(\mathrm{Mm} / \mathrm{min})\end{array}$ & $\begin{array}{c}(\mathrm{B}) \\
\text { Rotation } \\
(\mathrm{rpm})\end{array}$ & $\begin{array}{c}(\mathrm{C}) \\
\text { Depth of cut }(\mathrm{mm}) \\
(\mathrm{mm})\end{array}$ \\
\hline Level I & 960 & 4000 & 0.5 \\
Level II & 1080 & 4500 & 1.0 \\
Level III & 1200 & 5000 & 1.5 \\
\hline
\end{tabular}

Table 4. Taguchi $L_{9}$ Test design

\begin{tabular}{ccccc}
\hline $\begin{array}{c}\text { Test } \\
\text { No. }\end{array}$ & Variables & $\begin{array}{c}(\mathrm{A}) \\
\mathrm{f} \\
(\mathrm{Mm} / \mathrm{min})\end{array}$ & $\begin{array}{c}(\mathrm{B}) \\
\mathrm{S} \\
(\mathrm{rpm})\end{array}$ & $\begin{array}{c}(\mathrm{C}) \\
\mathrm{d} \\
(\mathrm{mm})\end{array}$ \\
\hline 1 & $\mathrm{~A}_{1} \mathrm{~B}_{1} \mathrm{C}_{1}$ & 1 & 1 & 1 \\
2 & $\mathrm{~A}_{1} \mathrm{~B}_{2} \mathrm{C}_{2}$ & 1 & 2 & 2 \\
3 & $\mathrm{~A}_{1} \mathrm{~B}_{3} \mathrm{C}_{3}$ & 1 & 3 & 3 \\
4 & $\mathrm{~A}_{2} \mathrm{~B}_{1} \mathrm{C}_{2}$ & 2 & 1 & 2 \\
5 & $\mathrm{~A}_{2} \mathrm{~B}_{2} \mathrm{C}_{3}$ & 2 & 2 & 3 \\
6 & $\mathrm{~A}_{2} \mathrm{~B}_{3} \mathrm{C}_{1}$ & 2 & 3 & 1 \\
7 & $\mathrm{~A}_{3} \mathrm{~B}_{1} \mathrm{C}_{3}$ & 3 & 1 & 3 \\
8 & $\mathrm{~A}_{3} \mathrm{~B}_{2} \mathrm{C}_{1}$ & 3 & 2 & 1 \\
9 & $\mathrm{~A}_{3} \mathrm{~B}_{3} \mathrm{C}_{2}$ & 3 & 3 & 2 \\
\hline
\end{tabular}

\section{Findings and Evaluation}

On Al 7075 material, the feed, cutting speed and chip depth parameters were used as a variable with DLC coated of DL1000 AXET 123504PEFR-S insert ends on the CNC milling machine and chip is removed. The effects of these parameters on surface roughness and cutting forces were examined.

Table 5 shows the surface roughness values and cutting force values obtained after the tests.

Table 5. Surface roughness and cutting force values measured at the end of the tests.

\begin{tabular}{cccc}
\hline $\begin{array}{c}\text { Test } \\
\text { No. }\end{array}$ & Variables & $\begin{array}{c}\text { Surface } \\
\text { Roughness } \\
(\mu \mathrm{m})\end{array}$ & $\begin{array}{c}\text { Cutting } \\
\text { Force } \\
(\mathrm{N})\end{array}$ \\
\hline 1 & $\mathrm{~A}_{1} \mathrm{~B}_{1} \mathrm{C}_{1}$ & 0.53 & 38.40 \\
2 & $\mathrm{~A}_{1} \mathrm{~B}_{2} \mathrm{C}_{2}$ & 0.49 & 61.67 \\
3 & $\mathrm{~A}_{1} \mathrm{~B}_{3} \mathrm{C}_{3}$ & 0.79 & 115.36 \\
4 & $\mathrm{~A}_{2} \mathrm{~B}_{1} \mathrm{C}_{2}$ & 0.98 & 66.07 \\
5 & $\mathrm{~A}_{2} \mathrm{~B}_{2} \mathrm{C}_{3}$ & 1.08 & 87.50 \\
6 & $\mathrm{~A}_{2} \mathrm{~B}_{3} \mathrm{C}_{1}$ & 0.76 & 28.45 \\
7 & $\mathrm{~A}_{3} \mathrm{~B}_{1} \mathrm{C}_{3}$ & 1.67 & 124.83 \\
8 & $\mathrm{~A}_{3} \mathrm{~B}_{2} \mathrm{C}_{1}$ & 1,22 & 40.83 \\
9 & $\mathrm{~A}_{3} \mathrm{~B}_{3} \mathrm{C}_{2}$ & 1.13 & 99.27 \\
\hline
\end{tabular}

\subsection{Evaluation of Surface Roughness Results}

The results of the experimental study performed to investigate the machinability of Al 7075 alloy material; roughness values were between 0.49 and $1.67 \mu \mathrm{m}$. S / N ratios of the surface roughness value according to the processing parameters are presented in Table 6 below. It is understood that for the final pass obtained in the nine experiments according to the $\mathrm{S} / \mathrm{N}$ ratio, when the feed was 960 $\mathrm{mm} / \mathrm{min}$, rotation $5000 \mathrm{rpm}$, and depth of chip $1 \mathrm{~mm}$, the most suitable surface quality could be achieved. But since in the tests carried out, this experiment process was not included, validation tests were carried out. Validation experiments were achieved, and a difference of $0.07 \mu \mathrm{m}$ was observed (Table 7). This result is consistent with the literature. High speed and low feed improve the quality of the surface. This is ultimately consistent with the theoretical and experimental studies, and Taguchi experiment demonstrates the compatibility of the design $[3,4,6]$. 
Table 6. Surface Roughness Values for Rations of $S / N$

\begin{tabular}{cccc} 
Level A & $($ Feed $\mathrm{mm} / \mathrm{min})$ & Level B $(\mathrm{rpm})$ & Level C (Cutting depth mm) \\
\hline 1 & 0.5206 & -0.4161 & 0.7355 \\
2 & 0.6302 & -1.2822 & -0.6397 \\
3 & -4.2446 & -1.3956 & -3.1897 \\
$\Delta_{\text {max-min }}$ & 4,8749 & 0.9795 & 3.9252 \\
Rank & 1 & 3 & 2
\end{tabular}

Table 7. Optimal Result for Surface Roughness Values

\begin{tabular}{llc}
\hline & Estimation & Verification Test \\
\hline Level & $\mathrm{A}_{1} \mathrm{~B}_{3} \mathrm{C}_{2}$ & $\mathrm{~A}_{1} \mathrm{~B}_{3} \mathrm{C}_{2}$ \\
Surface Roughness (N) & $0.44 \mu \mathrm{m}$ & $0.51 \mu \mathrm{m}$ \\
\hline
\end{tabular}

As a result of the experiments, the obtained Ra values and the Signal noise (S / N) ratios for each Ra value are presented in Figure 3. Besides, the effects of machining parameters on surface roughness are shown in Figures 4, 5 and 6.

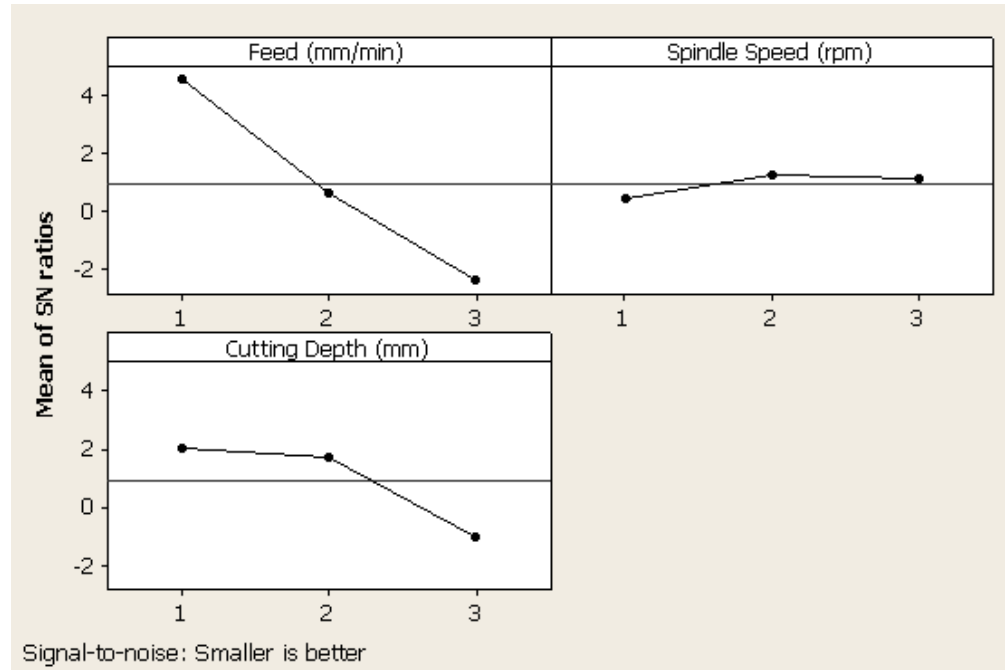

Figure 3. S/N Ratio

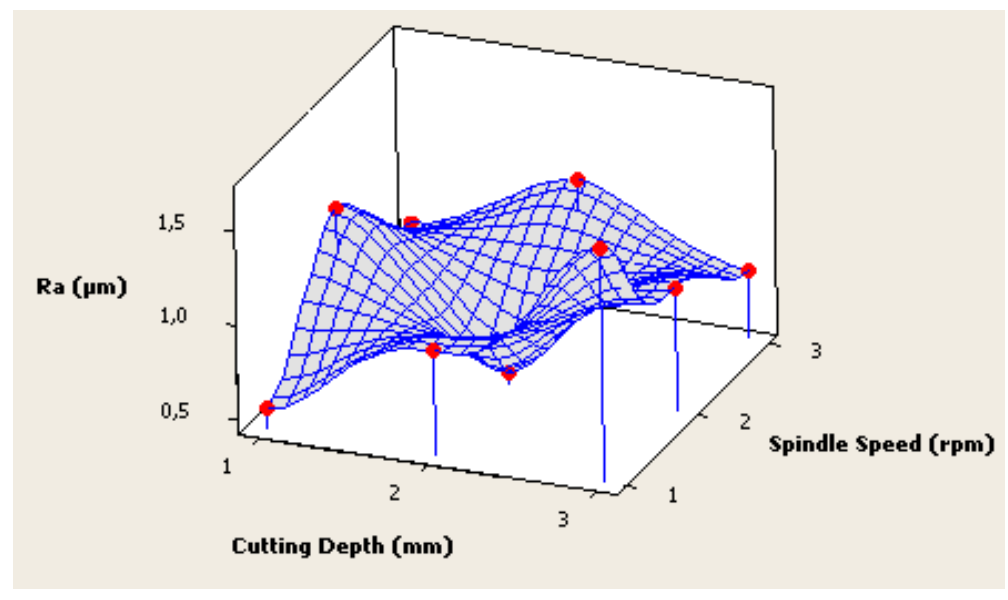

Figure 4. Effects of Rotation and Chip Depth on Surface Roughness 


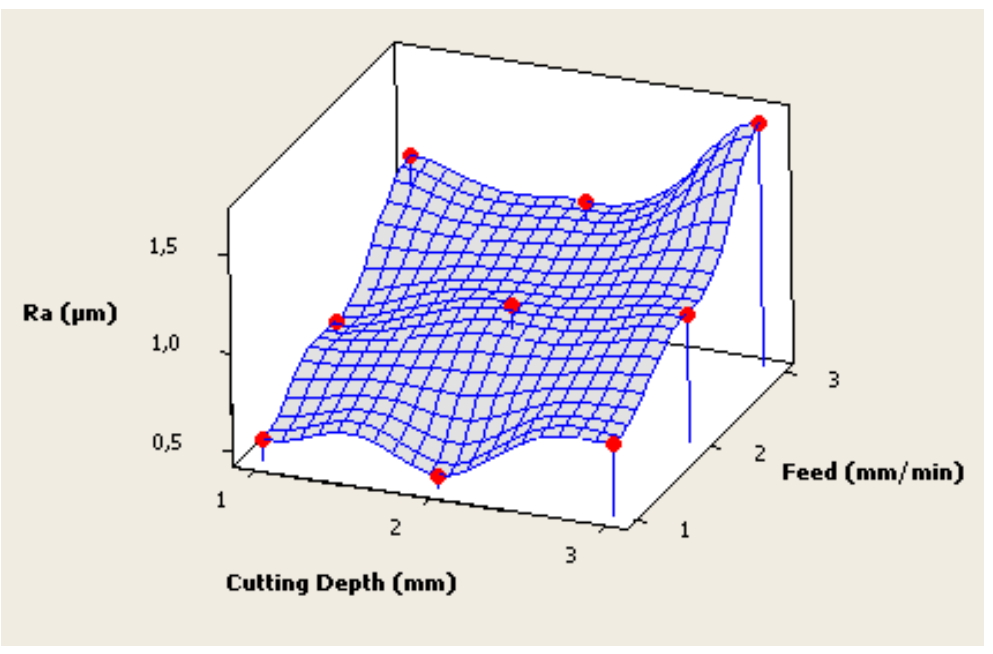

Figure 5. The Effects of Feed and Chip Depth on Surface Roughness

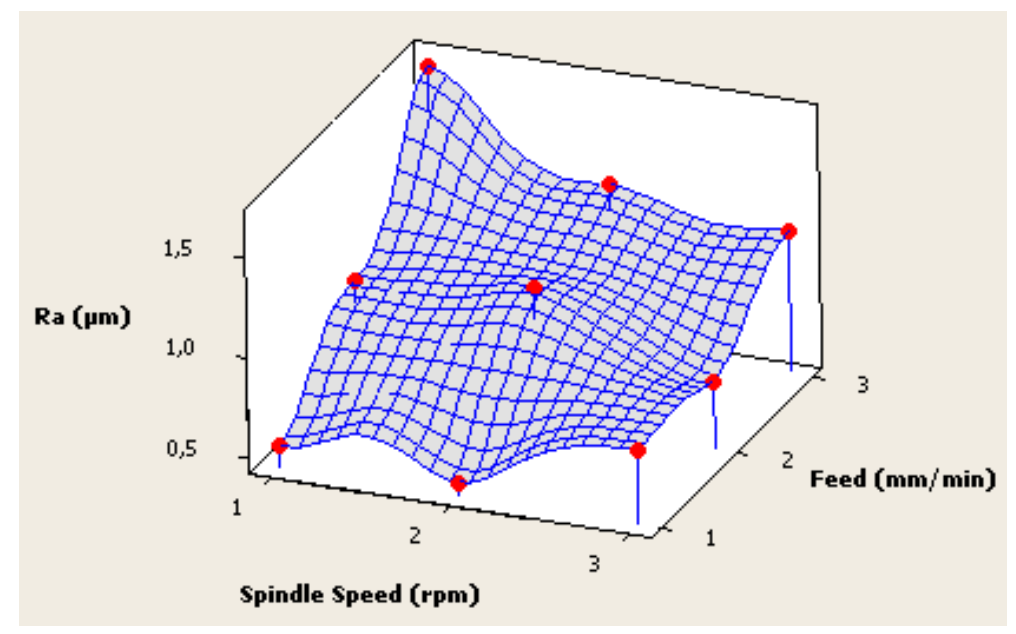

Figure 6. Effects of Rotation and Feed on Surface Roughness

\subsection{Evaluation of Cutting Force Results}

In machining of Al 7075 alloy material with the cutting tool by DLC coated, the resulting cutting force values were between 28.45 to $124.83 \mathrm{~N}$. S/N ratios of cutting force value concerning machining parameters are presented in Table 8 below. It is understood that for the final pass obtained in the nine experiments according to the $\mathrm{S} / \mathrm{N}$ ratio, when the feed was $1080 \mathrm{~mm} / \mathrm{min}$, rotation $5000 \mathrm{rpm}$, and depth of chip $0.5 \mathrm{~mm}$, the most suitable surface quality could be achieved. But since in the tests carried out, this experiment process was not included, validation tests were carried out. It is understood that the alteration in cutting force was affected by the feed rate, rotation, and cutting depth. Verification tests were performed, and it is understood that the difference was approximately $3 \mathrm{~N}$ (Table 9).

Table 8. Cutting Force Values for $S / N$ ratios

\begin{tabular}{cccc} 
Level & A (feed $\mathrm{mm} / \mathrm{min})$ & $\mathrm{B}(\mathrm{rpm})$ & $\mathrm{C}($ Cutting depth $\mathrm{mm})$ \\
\hline 1 & -36.24 & -36.67 & -31.00 \\
2 & -34.77 & -35.62 & -37.38 \\
3 & -38.03 & -36.75 & -40.67 \\
$\Delta$ max-min & 3.25 & 1.13 & 9.67 \\
Rank & 2 & 3 & 1 \\
\hline
\end{tabular}

Table 9. Optimal Results for Force

\begin{tabular}{lll}
\hline & Estimation & Verification Test \\
\hline Level & $\mathrm{A}_{2} \mathrm{~B}_{3} \mathrm{C}_{1}$ & $\mathrm{~A}_{2} \mathrm{~B}_{3} \mathrm{C}_{1}$ \\
Cutting Force Values (N) & $30.39 \mathrm{~N}$ & $33.1 \mathrm{~N}$ \\
\hline
\end{tabular}


As a result of the experiments, the obtained cutting force values and the signal noise $(\mathrm{S} / \mathrm{N})$ ratios for each shear force value are presented in Figure 7.

The effect of cutting depth, spindle rotation and the feed from the parameters effective in increasing cutting forces is revealed in Figure 8 , Figure 9 and Figure 10. As can be shown in the figures, with the increase in the depth of cut and the feed, the resistance to the cutter in the cutting plane increases and the cutting force value increases accordingly. However, this increase is not linear. It is possible to interpret that the reason why the cutting depth and feed increase is linear but the increase in cutting force is not linear, because of the consequence of the other parameters on the force of cutting.

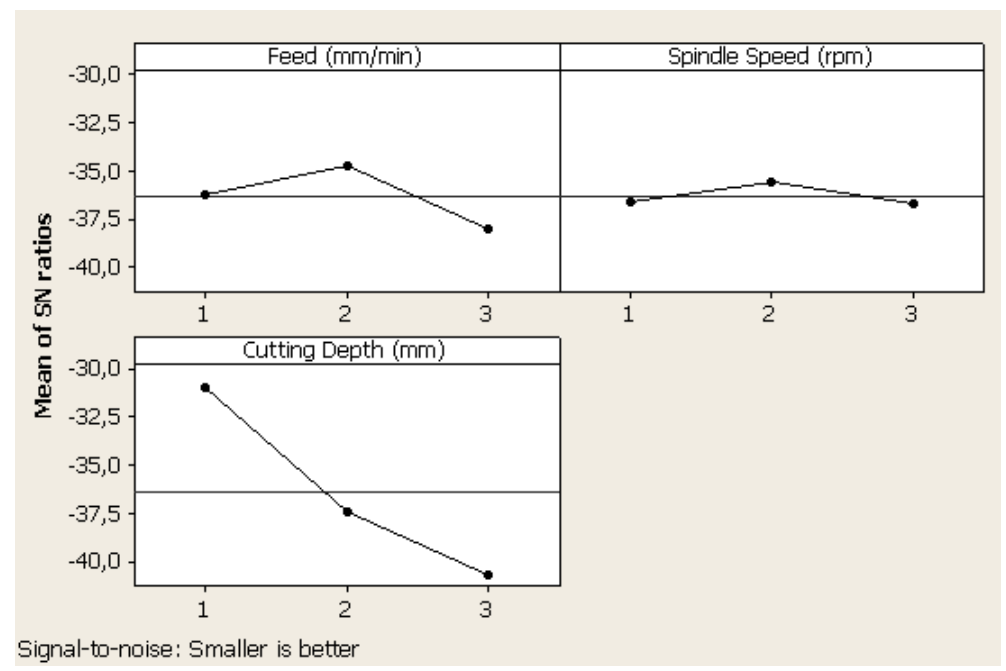

Figure 7. S/N Ratio

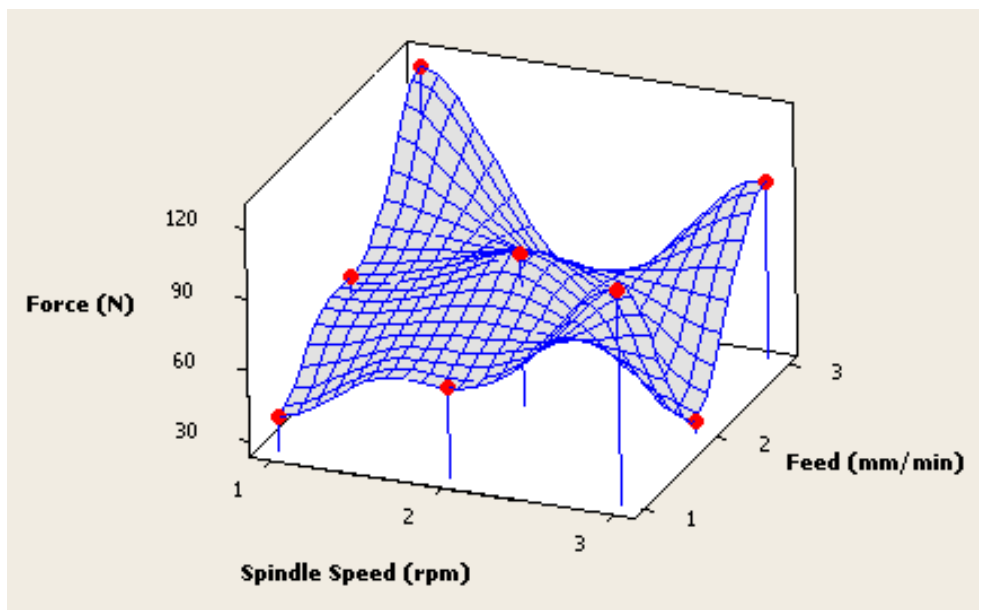

Figure 8. Effects of Rotation and Feed on Cutting Force

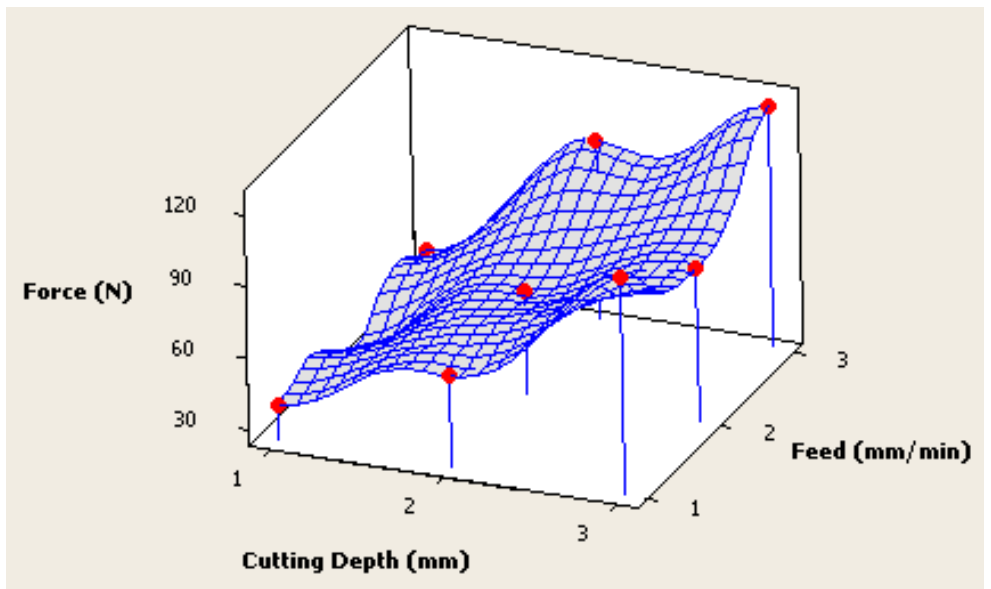

Figure 9. The Depth of Cut and Feed's Effects on Cutting Force 


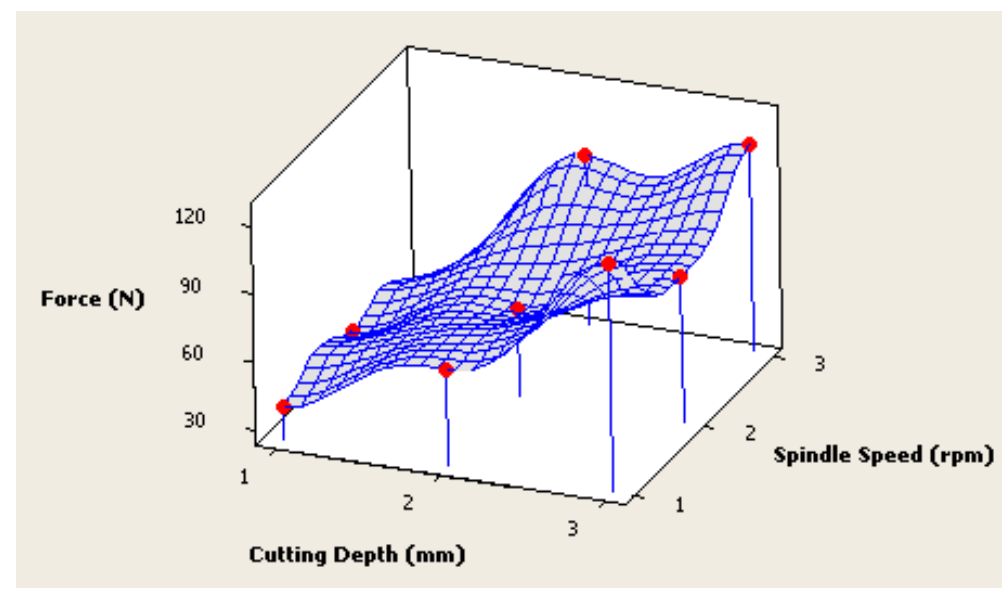

Figure 10. Effects of Rotation and Cutting Depth on Cutting Force

\subsection{Evaluation of Parameters with ANOVA Method}

Nine tests were made by using three different elements at three different levels for milling of Al 7075 alloy material, and different surface roughness and cutting force response values were measured in each test. Variance analysis was applied to clarify whether these differences were random or caused by the factors and the effects of each element on the response. The results of variance analysis of mean surface roughness and cutting force values are presented in Table 11 and Table 12. As shown in Table 11 and Figure 11, the most effective factor in the creation of roughness on the treated surface as a result of the treatment of Al 7075 alloy material with cutting tools by DLC coated is the feed with $92.46 \%$. In his study, Etyemez reported with $89.81 \%$, Ay and Karagöl reported with $92.47 \%$ of the cases feed was the most effective parameter. However, Pınar's study estimated the second effective parameter with $19.63 \%$ and the cutting speed with $29.12 \%$ as the first effective parameter. The fact that the feed is the active parameter seems to coincide with the literature $[3,4,6]$.

As seen in Table 12 and Figure 12, the most effective factor in the creation of cutting force is the cutting depth with $82.91 \%$ as a result of the machining of Al 7075-alloy material with cutting tools by DLC coated.

Table 11. ANOVA values corresponding to surface roughness values

\begin{tabular}{lcccrl}
\hline Notations: & $\begin{array}{l}\text { Degree of } \\
\text { Freedom }\end{array}$ & $\begin{array}{l}\text { Sum of } \\
\text { Squares }\end{array}$ & Variables & F rate & $\begin{array}{l}\text { Percentage } \\
(\%)\end{array}$ \\
\hline A & 2 & 0.81602 & 0.40801 & 73.59 & 92.46 \\
B & 2 & 0.04602 & 0.02301 & 4,15 & 6.22 \\
C & 2 & 0.21696 & 0.10848 & 19.57 & 1.28 \\
Error (e) & 2 & 0.01109 & 0.00554 & & 0.03 \\
Total & 8 & 1.09009 & & & 100 \\
\hline
\end{tabular}




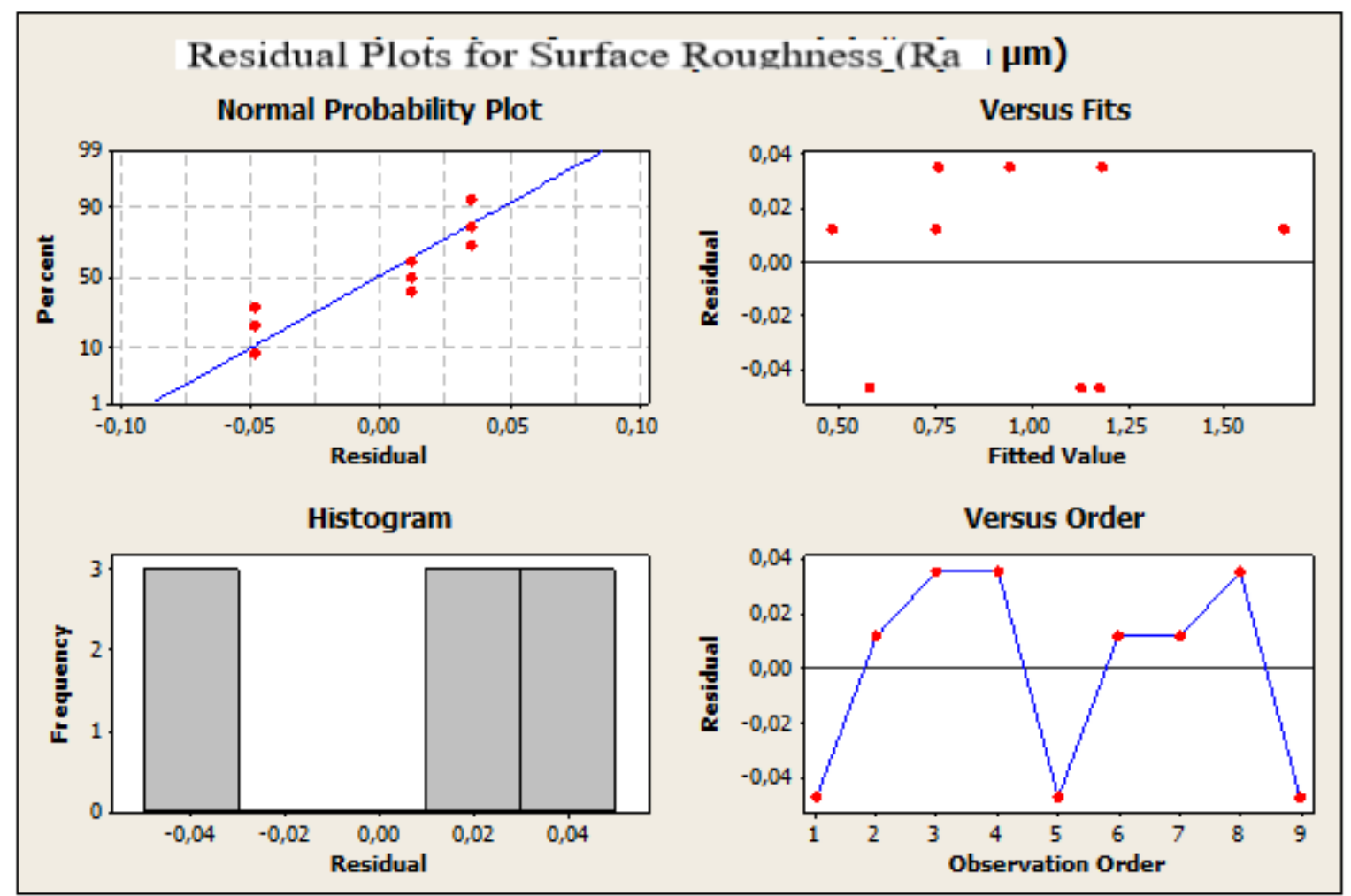

Figure 11. Surface Roughness for Variance Analysis Results

Table 12. ANOVA values corresponding to cutting force values

\begin{tabular}{lcrrrr}
\hline Notations: & $\begin{array}{l}\text { Degree of } \\
\text { Freedom }\end{array}$ & $\begin{array}{l}\text { Sum of } \\
\text { Squares }\end{array}$ & Variables & F rate & $\begin{array}{l}\text { Percentage } \\
(\%)\end{array}$ \\
\hline A & 2 & 1160.1 & 580.0 & 62.76 & 11.89 \\
B & 2 & 505.8 & 252.9 & 27.6 & 5.18 \\
C & 2 & 8086.7 & 4043.4 & 437.51 & 82.91 \\
Error (e) & 2 & 18.5 & 9.2 & & 0.02 \\
Total & 8 & 9771.0 & & & 100 \\
& & & & & \\
\hline
\end{tabular}




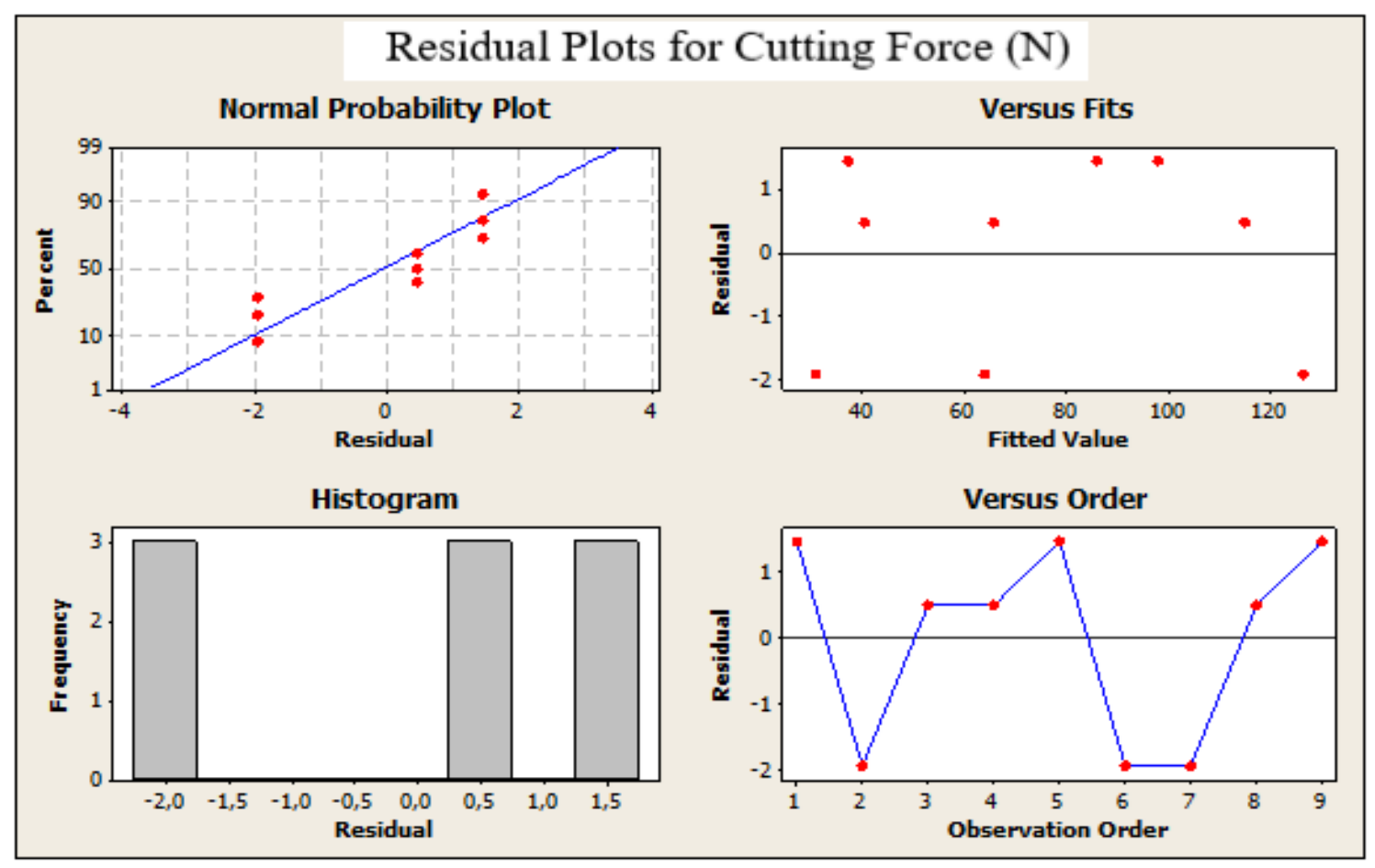

Figure 12. Cutting Force Variance Analysis Results

\subsection{Estimating Equation of Surface Roughness and Cutting Force with Regression Model}

Linear regression analysis was used to formulate and define the predicted equation between control factors (feed, cutting speed and depth of cut) used in chip removal and the result (average surface roughness and cutting force).

The Ra and $\mathrm{N}$ equations formulated for this experimental study are revealed below.

$\operatorname{Ra}(17 \mathrm{~m})=0,048+0,368 \mathrm{~A}-0,0833 \mathrm{~B}+0,172 \mathrm{C}+(\varepsilon) R^{2 n d}=0.947$

Force $(\mathrm{N})=-20,8+8,25 \mathrm{~A}+2,30+36,7 \mathrm{C}+(\varepsilon) \quad R^{2}=0.871$

\section{Conclusions}

In this study on machinability of $\mathrm{Al} 7075$, alloy material with DLC coated useful insert conclusions were reached. Conditions for machinability were surface roughness, cutting force, temperature and chip formation. Three control elements (feed rate, cutting speed and cutting depth), which are considered to be effective in realization of this criterion under ideal conditions, were selected at three different levels and applied in the experimental study. The results are summarized below.

- In the machining of Al 7075 alloy material with DLC coated cutting tools, the ideal surface roughness value was obtained as feed was $960 \mathrm{~mm} / \mathrm{min}$, the rotation was $5,000 \mathrm{rpm}$, and the depth of the cut was $1 \mathrm{~mm}$.

- All three control factors (feed, rotation and depth of cut) were also useful in the formation of cutting force. The ideal cutting force value was reached with the feed of $1080 \mathrm{~mm} / \mathrm{min}$, rotation was $5000 \mathrm{rpm}$ and cutting depth is $0.5 \mathrm{~mm}$.

- It is seen that the Taguchi optimization technique is a useful technique in the design of the workability test of Al 7075 alloy material, optimization of parameters, and obtaining the desired rates of response values.

- In the outcomes found from the experimental studies with the variance analysis (ANOVA); the most genuine factor in the creation of surface roughness is $92.47 \%$ feed, the most effective factor in the formation of cutting force is $82.91 \%$ depth of chip.

- With the regression analysis, Ra's predictive equation was obtained with an accuracy of $94.7 \%$, and the force estimation of the equation with $87.1 \%$ accuracy. 
When the results are assessed in consideration of the literature, it is found out that DLC coatings contribute positively to the workability of Aluminum 7075 alloy material and mainly accelerates the enhancement in the performance of the cutting tool.

\section{References}

[1] Kaya, H. Cengiz, A. Uçar, M. Talaş formuna bağlı olarak 7075 Al Alaşımının işlenebilirlik parametrelerinin uygunluğunun tespit edilmesi. 2. Ulusal Talaşl Imalat Sempozyumu Konya. (77-91), (2010).

[2] Pınar, A.M. AA 6013 Alüminyum Alaşımının Frezelenmesinde Kesme Parametreleri Etkilerinin Ortalama ve Toplam Yüzey Pürüzlülüğü Kriterine Göre İncelenmesi. NWSA:Technological Applied Sciences, 5-1(15-2), (2010).

[3] Sekmen M., Günay M., Şeker U. Alüminyum Alaşımlarının İşlenmesinde Kesme Hızı ve Talaş Açısının Yüzey Pürüzlülüğü, Yığıntı Talaş ve Yığıntı Katmanı Oluşumu Üzerine Etkisi. Journal of Polytechnic, 18-3(141-148), (2015).

[4] Etyemez, A. Optimization of Effects of Pocket Tool Path Strategies and Cutting Parameters on Surface Quality. Acta Physica Polonica A, 129-4(886-889), (2016).

[5] Ay, M., Etyemez, A. Optimization of Effects of Cutting Parameters and Cutting Tool Path by using Grey Based Taguchi Method. Acta Physica Polonica, A, 134-1(125-128), (2018).

[6] Ay M., Karagöl T. Investigation of the machinability of the Al 7075 alloy using DLC coated cutting tools. Scientific Research and Essays, 6-1(44-51), (2011).

[7] List G., (2015).Wear behavior of cemented carbide tools in dry machining of aluminium alloy, Wear,

259:7-12, 1177-1189.

[8] Korkut I., Korkut, I., Donertas, M.A. The influence of feed rate and cutting speed on the cutting forces, surface roughness and toolchip contact length during face milling. Materials and Design, 28 (308-312), (2007).

[9] Sevim, C., . Genç, O. Al-7075 Malzemesinin Freze Tezgâhında Delme İşleminde Farklı Devir Ve İlerleme Hızları İçin Oluşan Titreşimlerin İncelenmesi. International Journal Of Scientific\& Technology Research, 4-4(50-57), (2015).

[10] Camposeco-Negrete C. Optimization of cutting parameters using Response Surface Method for minimizing energy consumption and maximizing cutting quality in turning of AISI 6061 T6 aluminum. Journal of Cleaner Production, 91(109-117), (2015).

[11] Liu Y, Meletis E, Erdemir A. A study on wear mechanism of diamond-like carbon films. Surf. Coatings Technol., 82(48-56), (1996).

[12] Settineri L, Bucciotti F, Cesano F, Faga MG. Surface Properties of Diamond Coatings for Cutting Tools. Ann. CIRP, 56(573-576), (2007)

[13] Trava-Airoldi VJ, Bonetti LF, Capote G, Santos LV, Corat EJ. A comparison of DLC film properties obtained by r.f. PACVD, IBAD, and enhanced pulsed-DC PACVD. Surf. Coatings Technol., 202(549-554), (2007).

[14] Uenga HY, Guo CT, Dittrich KH. Development of a hybrid coating process for deposition of diamond-like carbon films on microdrills. Surf. Coatings Technol., 200(2900-2908), (2007).

[15]Vandevelde TCS, Vandierendonck K, Van Stappen M, Du Mong W, Perremans P. Cutting applications of DLC, hard carbon, and diamond films. Surf. Coatings Technol.,113(80-85), (1999).

[16] Deepak D., Rajendra B Investigations on the surface roughness produced in turning of Al 6061 (as-cast) by Taguchi method. International Journal of Research in Engineering and Technology, 4-8(295-298), (2015).

[17] Chandra Sekhar, Y., Gopichand, A., Sam Sukumar, R., Pavan Kumar, N. Optimization of Surface Roughness of 6463 Aluminium Alloy and Brass Materials in CNC Milling Operation Using Taguchi's Design. International Journal of Innovative Research in Science, Engineering and Technology, 6-2 (1553- 1560), (2017).

[18] Sakthivelu, S., Anandaraj, T., Selwin, M. Multi-Objective Optimization of Machining Conditions on Surface Roughness and MRR during CNC End Milling of Aluminium Alloy 7075 Using Taguchi Design of Experiments. Mechanics and Mechanical Engineering, 21-1(95-103), (2017).

[19] Saravanakumar, A., Sasikumar, P., Nilavusri, N. Optimization of Machining Parameters using the Taguchi Method for Surface Roughness. J. Mater. Environ. Sci., 7-5(1556-1561), (2016).

[20] Yaşar, N., Yurtkuran, H., Günay, M. Sertleştirilmiş X40CrMoV5-1 Çeliğinin Tornalanmasında Kesme Kuvvetinin Deneysel ve Nümerik Olarak İncelenmesi. GU J Sci, Part C, 6-4 (765-773), (2018).

[21] Satish Kumar, M. D., Prasad, J., Abhishek Krishna, D., Venkat Narayana, M., Anusha, M., Saravanakumar A. Parametric optimization of aluminum alloy milling using Taguchi method for surface roughness. International Journal of Scientific Research and Review, 7-3(517-522), (2018).

[22] Ay, M., Altunpak, Y. Optimization of cutting parameters and graphite rate in the drilling of a hybrid aluminum matrix composites. Journal of Engineering and Fundamentals, 2-2, (42-50), (2015).

[23] Ay, M., Basmac1, G. Investigation of The Effects of Conventional and Wiper Coated Carbide Tools With Dry Cutting on Cutting Forces, Surface Roughness and Material Hardness In Turning 17-4 Ph Stainless Steel. The Online Journal of Science and Technology, 6-1, (33-39), (2016). 